\title{
Performance of 'Emerald' and 'Jewel' blueberry cultivars under no-chill incidence ${ }^{1}$
}

\author{
Ricardo Bordignon Medina², Tatiana Eugenia Cantuarias-Avilés², \\ Sergio Figueiredo Angolini², Simone Rodrigues da Silva ${ }^{2}$
}

\section{ABSTRACT}

Climate is a limiting factor for cultivating blueberries in new areas in Brazil, being the commercial production restricted only to the colder and high-altitude regions of the southern states. This study aimed to evaluate the performance of lowchill requirement 'Emerald' and 'Jewel' blueberry cultivars. For that, the stages of vegetative growth, sprouting, flowering fruiting and yield were assessed. The 'Emerald' cultivar has two peaks for both flowering and fruiting, with the main harvest period occurring between August and October, while the 'Jewel' cultivar shows two peaks for budding, but only one flowering peak and only one harvest, which extends from October through January. For both cultivars, the production occurs during the off-season of the internal and external markets, resulting in higher fruit prices. Growing both cultivars is feasible in a subtropical region with no-chill incidence, thus demonstrating that these cultivars have much lower chill requirements than those referred to in the literature, and favoring, this way, the fresh fruit production during the off-season of the main producing countries in the northern hemisphere.

KEYWORDS: Vaccinium spp.; flowering; fruiting; chill hours requirement.

\section{INTRODUCTION}

Due mainly to its nutraceutical properties and gastronomic versatility, the growing demand for blueberry (Vaccinium spp.) has driven a significant increase in the world production, in recent years, from approximately 144,000 tons in 1998 to 552,000 tons in 2016, led by countries such as the United States, Canada, Chile, Mexico, Poland and Germany (Brazelton 2015, FAO 2018).

The United States and Canada are also the largest consumers, with the production being inadequate to keep up with the consumers demands, particularly in the off-season. This creates an

\section{RESUMO}

Mirtileiros 'Emerald' e 'Jewel' cultivados em ausência de frio hibernal

O clima é um fator limitante à expansão do cultivo de mirtileiro para novas áreas no Brasil, sendo comercialmente viável apenas nas regiões mais frias e de altitude dos estados do Sul. Objetivou-se avaliar o desempenho das cultivares de mirtilo 'Emerald' e 'Jewel', de baixa exigência em frio. Foram caracterizadas as fases de crescimento vegetativo, brotação, florescimento, frutificação e produção de frutos. A cultivar 'Emerald' apresenta dois picos de florescimento e frutificação, com a colheita principal ocorrendo de agosto a outubro, enquanto a cultivar 'Jewel' apresenta dois picos de emissão de botões florais, mas apenas um pico de florescimento e uma única colheita, que ocorre entre outubro e janeiro. Para ambas as cultivares, a produção ocorre durante o período de entressafra do mercado interno e externo, o que possibilita melhores preços para a fruta. É possível produzir ambas as cultivares em região subtropical sem a incidência de frio hibernal, demonstrando, assim, que essas cultivares apresentam menor exigência em frio do que relatado na literatura, e favorecendo a produção de frutos frescos na entressafra dos principais países produtores do hemisfério Norte.

PALAVRAS-CHAVE: Vaccinium spp.; florescimento; frutificação; exigência de horas de frio.

attractive commercial opportunity for South American countries such as Chile, Uruguay and Argentina (Fachinello 2008) and, more recently, countries such as Mexico, Peru, Colombia and Brazil (Brazelton 2013, Cantuarias-Avilés et al. 2014).

Although the volume of fresh blueberries exported by Brazil is still quite low, the country has some comparative advantages for export, such as the proximity to the European markets and the abundance of naturally acidic soils favorable for the development of this crop (Cantuarias-Avilés et al. 2014). The São Paulo state is Brazil's most significant consumer of fresh blueberries, which are produced between November and April, from domestic groves, 
while imported blueberries, mainly from the United States, Chile, Argentina, Spain, Italy and Portugal, are available between May and October (Fagundes 2007).

Due to the requirement of cold weather to induce blooming (Olmstead et al. 2015), the growing of blueberry plants in Brazil has been restricted to the three states of the southern region and to some high-altitude regions in the states of São Paulo and Minas Gerais, at elevations of 1,600 m and 1,200$1,500 \mathrm{~m}$, respectively.

There are two varietal groups that are grown commercially in Brazil: the Rabbiteye group, which currently includes the most common cultivars, requiring 300-650 chill hours; and the Southern Highbush group, including cultivars such as 'Misty' and 'O'Neal', which were introduced to Brazil in 2000 and are planted in frost-free southern regions of the country, requiring at least 250 chill hours to induce fruit production, and are not well adapted to hot climates (Cantuarias-Avilés et al. 2014).

The gradual increases in air temperature recorded in the last decades around the world have restricted the areas suitable for temperate fruit crops. This emphasizes the need for programs involving cold weather stone fruit trees and berries that seek to develop less cold-dependent cultivars (Byrne 2005, Lyrene 2008). Such programs have already reached some success in areas of low cold incidence, such as southern California, Hawaii, Mexico, Spain and Portugal (Hummer et al. 2007).

Blueberry cultivars of the Southern Highbush group, developed by the University of Florida, that have low to very low cold weather dependence (100400 h) (Lyrene 2008), were introduced into Brazil in 2010. The introduction of these cultivars aims to facilitate the expansion of the blueberry cultivation and diversify the fruit production, especially among small producers with family labor.

This study aimed to evaluate the performance of 'Emerald' and 'Jewel' blueberry cultivars planted under subtropical climate, with no cold winter period.

\section{MATERIAL AND METHODS}

The study was conducted between 2014 and 2015 , in a commercial plantation with 'Jewel' and 'Emerald' blueberry cultivars, in Piracicaba,

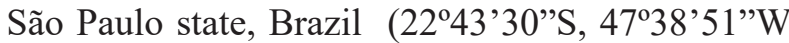
and Cwa climate, by the Köppen and Geiger classification). The plants were disposed in a semi-protected environment, covered with lowdensity polyethylene and with the sides open. The monthly averages of minimum, mean and maximum temperatures $\left({ }^{\circ} \mathrm{C}\right)$ (Table 1) were obtained from the meteorological station of the Escola Superior de Agricultura Luiz de Queiroz, situated $7 \mathrm{~km}$ from the study site. Air temperature data were measured every $15 \mathrm{~min}$ and compiled to calculate the number of chill hours below $7.2^{\circ} \mathrm{C}, 10^{\circ} \mathrm{C}, 12^{\circ} \mathrm{C}$ and $15^{\circ} \mathrm{C}$ (Table 1 ).

Thirty 3-year-old plants of each cultivar ('Jewel' and 'Emerald') were placed at a spacing of $2.0 \mathrm{~m}$ x $0.8 \mathrm{~m}\left(6,250\right.$ plants ha $\left.{ }^{-1}\right)$, in $12 \mathrm{~L}$ pots containing a commercial substrate of pine bark and fertigation. Plants were pruned to a height of $20 \mathrm{~cm}$, at five months before starting the evaluations. The new shoots that grew after pruning were evaluated from May 2014, regarding the following variables:

Growth and sprouting: one shoot per plant was selected from each cultivar and tagged after counting 12 nodes from the meristematic apex downwards, being its length measured every four weeks from the previously marked point to the terminal pair of leaves, using a tape measure. The average monthly shoot growth rate, expressed in $\mathrm{cm} \mathrm{month}^{-1}$, was calculated from the difference between consecutive shoot length evaluations in 30 shoots per cultivar. The average monthly shoot sprouting rate, expressed as the mean number of sprouts per month, was calculated from the counts of lateral sprouts emitted on the tagged shoots, as well as those emitted from any lateral sprout grown in the tagged shoot portion;

Characterization of the flowering and fruiting phases: in each cultivar, two branches were selected per plant and the number of flower buds and flowers were evaluated fortnightly until the petals fell off;

Fruit yield: the number of fruits per plant was estimated from the average number of productive branches per plant, counted in seven plants of each cultivar, and the average number of fruits per branch, recorded in 60 branches sampled per cultivar. Fruit yield ( $\left.\mathrm{kg} \mathrm{plant}^{-1}\right)$ was estimated by multiplying the estimated number of fruits per plant by the average individual fruit mass $(1.5 \mathrm{~g})$;

Productivity: calculated by multiplying the estimated fruit yield $\left(\mathrm{kg} \mathrm{plant}^{-1}\right)$ by the density of 6,250 plants $\mathrm{ha}^{-1}$, being expressed in $\mathrm{kg} \mathrm{ha}^{-1}$.

The experiment was arranged in a completely randomized design, with 30 plants (replications) per cultivar. Descriptive statistical tools were applied 
Table 1. Monthly average values of mean (Tmed), maximum (Tmax) and minimum (Tmin) temperature and number of monthly hours with temperature below $15^{\circ} \mathrm{C}(\mathrm{CH}<15), 12{ }^{\circ} \mathrm{C}(\mathrm{CH}<12), 10{ }^{\circ} \mathrm{C}(\mathrm{CH}<10)$ and $7.2{ }^{\circ} \mathrm{C}(\mathrm{CH}<7.2)$, in Piracicaba, São Paulo state, Brazil, between January 2014 and May 2015.

\begin{tabular}{|c|c|c|c|c|c|c|c|}
\hline \multirow{2}{*}{ Month } & Tmed & Tmax & Tmin & $\mathrm{CH}<15$ & $\mathrm{CH}<12$ & $\mathrm{CH}<10$ & $\mathrm{CH}<7.2$ \\
\hline & \multicolumn{3}{|c|}{${ }^{\circ} \mathrm{C}$} & \multicolumn{4}{|c|}{$\mathrm{h}$} \\
\hline January/2014 & 26.8 & 34.4 & 20.5 & 0 & 0 & 0 & 0 \\
\hline February/2014 & 26.3 & 33.5 & 20.3 & 0 & 0 & 0 & 0 \\
\hline $\operatorname{March} / 2014$ & 24.6 & 31.7 & 19.2 & 0 & 0 & 0 & 0 \\
\hline April/2014 & 22.6 & 29.5 & 16.8 & 39 & 6 & 0 & 0 \\
\hline May/2014 & 19.8 & 27.1 & 13.6 & 133 & 15 & 2 & 0 \\
\hline June/2014 & 19.2 & 270 & 12.6 & 173 & 58 & 23 & 4 \\
\hline July/2014 & 18.4 & 26.1 & 11.8 & 201 & 67 & 19 & 1 \\
\hline August/2014 & 20.0 & 29.0 & 11.8 & 192 & 55 & 7 & 0 \\
\hline September/2014 & 22.8 & 31.1 & 16.1 & 39 & 6 & 0 & 0 \\
\hline October/2014 & 24.3 & 32.6 & 16.6 & 47 & 4 & 0 & 0 \\
\hline November/2014 & 24.6 & 31.5 & 19.4 & 6 & 0 & 0 & 0 \\
\hline December/2014 & 25.9 & 33.2 & 20.7 & 0 & 0 & 0 & 0 \\
\hline January/2015 & 27.6 & 35.3 & 22.0 & 0 & 0 & 0 & 0 \\
\hline February/2015 & 26.0 & 33.4 & 21.2 & 0 & 0 & 0 & 0 \\
\hline $\operatorname{March} / 2015$ & 25.0 & 31.6 & 20.7 & 0 & 0 & 0 & 0 \\
\hline April/2015 & 23.2 & 30.2 & 17.6 & 12 & 0 & 0 & 0 \\
\hline May/2015 & 20.4 & 27.1 & 15.1 & 28 & 0 & 0 & 0 \\
\hline Total & - & - & - & 867 & 211 & 51 & 5 \\
\hline
\end{tabular}

for analyzing data on vegetative growth, budding, flowering, fruiting and fruit yield.

\section{RESULTS AND DISCUSSION}

'Emerald' blueberry plants presented two main periods of shoot growth, with the highest peak observed in June and a smaller one in October, both characterized by the emergence of new shoots (Figure 1A). 'Jewel' blueberry plants also had two periods of shoot growth, but in both the shoots were shorter than those of the 'Emerald' plants, with the first peak occurring also in June, and a second one recorded between November and December. For the 'Jewel' cultivar, three peaks of lateral sprouting were identified on the tagged shoots, the first in October 2014 and the other one in January and February 2015 (Figure 1B).

In 'Emerald' blueberry plants, lateral sprouting peaks were recorded from August onwards (Figure 1A), after the main shoots had ceased to grow. This process was likely enhanced by the occurrence of high temperatures from August onwards, in the experimental site (Table 1), that increased metabolic rates and promoted shoot sprouting. Zheng et al. (2017) found that increases in temperature enhanced dramatically the growth of four Southern
Highbush cultivars through the warming effect, demonstrating an optimal temperature ranging from $29.0^{\circ} \mathrm{C}$ to $32.6^{\circ} \mathrm{C}$. They also found that physiological parameters, such as leaf photosynthesis, stomatal conductance and transpiration, had similar trends as plant growth in response to temperatures, suggesting

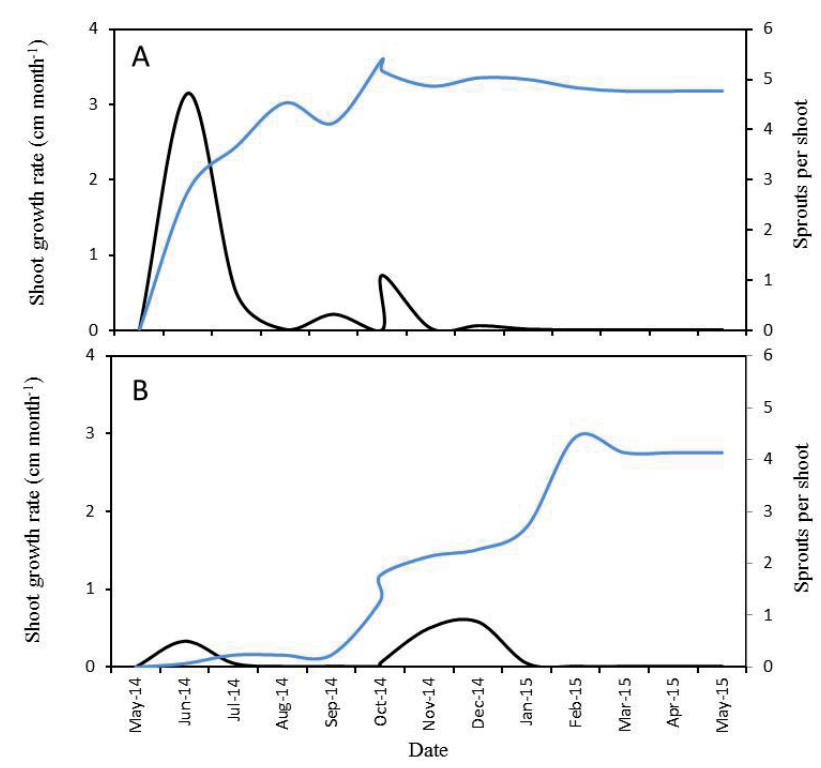

Figure 1. Average shoot growth rate (black) and number of sprouts per shoot (blue) in 'Emerald' (A) and 'Jewel' (B) blueberry plants. 
that the biochemical and photochemical processes of blueberry plants are boosted by the optimal growth temperature. The emergence of new lateral sprouts allows an increase in the plant productive potential, since it guarantees the renewal of the productive branches and the continuity of fruit production in time. For the 'Jewel' cultivar, two peaks of lateral sprouting were recorded in October 2014 and February 2015 (Figure 1B).

In this study, the 'Emerald' and 'Jewel' cultivars had different periods of flowering and fruiting (Figure 2). For the 'Emerald' plants, about $50 \%$ of the flower buds emerged between late May and late June 2014, resulting in a first flowering peak between mid-June and late July (Figure 1A). For this cultivar, the duration of the flowering stage was 56 days, although $42 \%$ of the flowers emerged at the end of this phase, between the second and fourth week of July. Harvesting began in August, with a peak at the beginning of September. A total of $75 \%$ of the fruits were harvested between the second week of August and the third week of October. A second peak of flower buds occurred in the third week of September until the first week of October, which produced fruits from the second half of November until the beginning of January, 2015. The main harvest period observed in the 'Emerald' cultivar is particularly interesting
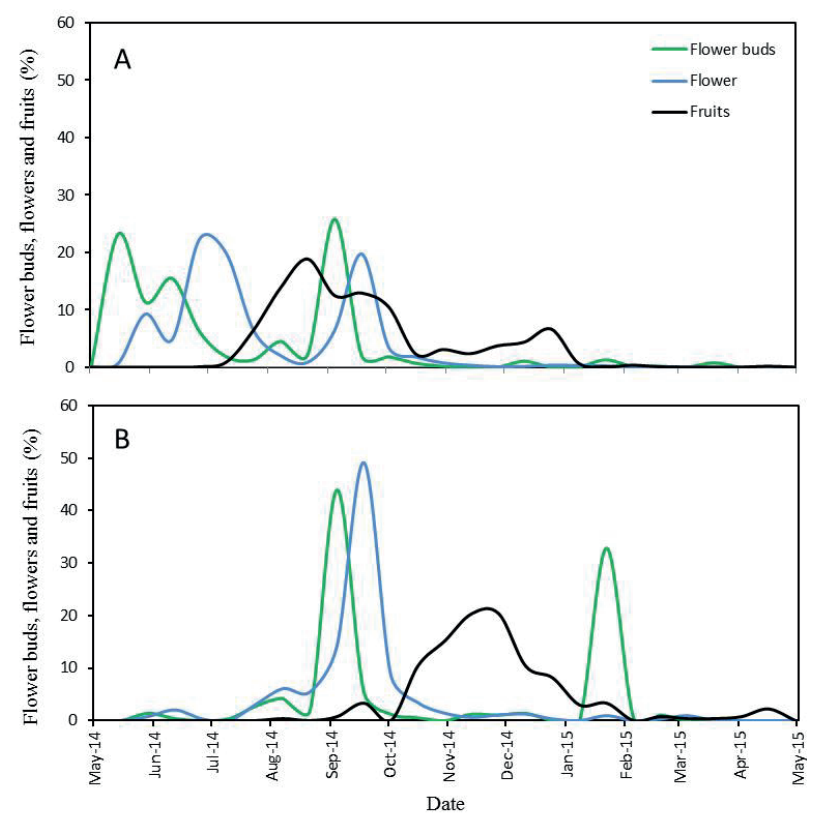

Figure 2. Percentages of flower buds (green), flowers (blue) and fruits (black) in shoots of 'Emerald' (A) and 'Jewel' (B) blueberry plants. for fresh fruit export, as it may be able to supply the North hemisphere's markets during the off-season period extending from August to March.

'Jewel' plants produced flower buds later than 'Emerald' plants, with a main peak of flower buds registered in the third week of September, that came into flowering at the first week of October. For this cultivar, a second peak of flower buds was observed in early February 2015; however, these buds did not complete their development and aborted, most likely due to the high temperatures recorded during this period (Table 1).

Flowering of the 'Jewel' blueberry cultivar (Figure 2B) extended over 30 days and was more concentrated and shorter than that of the 'Emerald' cultivar (Figure 2A). For the 'Jewel' cultivar, fruit harvest happened later, but in a more concentrated way (Figure 2B) than in the 'Emerald' cultivar (Figure 2A), starting at the end of October 2014 and ending at the second week of January 2015, with $85 \%$ of the fruits being harvested in this period (Figure 2B). Distinctly, a second fruit crop of smaller intensity was harvested from the 'Emerald' plants in January 2015 (Figure 2).

Other studies involving 'Jewel' and 'Emerald' blueberry cultivars grown in warm climates in Hawaii (Hummer et al. 2007) and Florida (Lyrene 2008), USA, also described a later flowering period of 'Jewel' plants, as compared to the 'Emerald' cultivar. In Florida, 'Emerald' blueberry plants flowered from January to February (corresponding to the months of July to August in the southern hemisphere), and produced large, firm and sweet fruits from April to May (October to November in the southern hemisphere) (Lyrene 2008), with more concentrated and different fruiting periods than those observed in this study.

In Florida, both cultivars required at least $100 \mathrm{~h}$ of air temperature below $7.2{ }^{\circ} \mathrm{C}$, in order to flourish (Lyrene 2008). Such temperature threshold did not occur at the experimental site in Piracicaba (Table 1), and it is not necessary to stimulate flowering in both studied blueberry cultivars.

In Hawaii, Hummer et al. (2007) stated that the lack of low temperatures necessary for breaking bud dormancy did not affect the productivity of Southern Highbush genotypes, including 'Jewel' and 'Emerald'. In the United States, Norvell \& Moore (1982) concluded that temperatures between $1{ }^{\circ} \mathrm{C}$ and $12{ }^{\circ} \mathrm{C}$ were sufficient to meet the cold needs of Southern Highbush blueberry plant genotypes. 
During the present study, a total of $211 \mathrm{~h}$ below $12{ }^{\circ} \mathrm{C}$ were recorded (Table 1), suggesting that this temperature threshold would be far more adequate for satisfying the thermal requirements for the bud breaking of 'Jewel' and 'Emerald' plants cultivated in a subtropical climate, as opposed to the value of $7.2^{\circ} \mathrm{C}$ defined for these cultivars in Florida (Lyrene 2008).

Under local subtropical conditions, the later flowering of the 'Jewel' blueberry cultivar (Figure 2B) is and indicative of its higher requirement of winter chill accumulation for floral bud breaking, when compared to 'Emerald' plants.

When cultivated in a subtropical region with a lower incidence of winter cold, the 'Jewel' and 'Emerald' blueberry plants are stimulated to vegetate, bloom and produce at different periods throughout the year, unlike what occurs in colder regions, where the same cultivars have one period of flowering and a single and more concentrated fruiting event (Lyrene 2008, Ogden \& Iersel 2009). The occurrence of successive shooting and flowering events recorded for the 'Jewel' and 'Emerald' cultivars, when cultivated in warmer regions, makes plant management more complex.

The average fruit yield of 'Emerald' plants was $125 \%$ greater than that of the 'Jewel' cultivar, in the assessed period (Table 2). This difference may be attributed to the fact that, for the 'Emerald' plants, both the first and the second flowering events resulted in fruit production, while, for the 'Jewel' plants, the second blooming failed to produce fruits, as it occurred during a very hot weather period (February) (Table 1). The total flower rate emission in the 'Emerald' plants was $205 \%$ greater than that of the 'Jewel' cultivar. The higher production of 'Emerald' blueberry plants may also be related to its faster shoot growth rate and larger number of lateral sprouts, as compared to the 'Jewel' cultivar (Figure 1).

In Hawaii, Hummer et al. (2007) evaluated six Southern Highbush cultivars, including 'Emerald' and 'Jewel', and observed that 'Jewel' plants showed

Table 2. Estimated fruit number, weight and yield in 'Emerald' and 'Jewel' blueberry plants.

\begin{tabular}{lccc}
\hline \multirow{2}{*}{ Cultivar } & \multicolumn{3}{c}{ Production variable } \\
\cline { 2 - 4 } & Fruits plant & $\begin{array}{c}\text { Fruit weight } \\
\left(\mathrm{kg} \mathrm{plant}^{-1}\right)\end{array}$ & $\begin{array}{c}\text { Yield } \\
\left(\mathrm{kg} \mathrm{ha}^{-1}\right)\end{array}$ \\
\hline 'Emerald' & 250 & 0.38 & $2,347.7$ \\
'Jewel' & 111 & 0.17 & $1,038.5$ \\
\hline
\end{tabular}

less flowering and fruiting. The authors attributed this occurrence to the strong and vigorous plant growth of this cultivar, which might have been detrimental to flower development. This pattern was not observed in this study, as the average shoot growth of 'Jewel' plants (Figure 1B) was smaller than for 'Emerald' plants (Figure 1A).

The blueberry production is highly variable depending on the cultivar, production system and cultivation site. In Hawaii, in a humid subtropical climate (Cfa, according to the Köppen and Geiger classification), Hummer et al. (2007) obtained yields of $0.94 \mathrm{~kg} \mathrm{plant}^{-1}$ and $0.42 \mathrm{~kg}$ plant $^{-1}$ for the cultivars 'Emerald' and 'Jewel', respectively, higher than those observed in this study (Table 2). However, in a study conducted in Georgia, USA, in a subtropical humid climate region (Cfa, according to the Köppen and Geiger classification), with Southern Highbush blueberries also grown under protected environment and at high planting density $(1.0 \mathrm{~m} \times 0.75 \mathrm{~m})$, Ogden \& Iersel (2009) reported yields similar to those of this study, obtaining $0.31 \mathrm{~kg}$ plant $^{-1}$ and $0.17 \mathrm{~kg}$ plant ${ }^{-1}$, respectively for the 'Emerald' and 'Jewel' cultivars.

In another study conducted in California, USA, under a local steppe climate (BSk), the fruit yield of 'Emerald' and 'Jewel' plants grown in an open field, at a spacing of $3.4 \mathrm{~m} \times 0.9 \mathrm{~m}\left(3,268\right.$ plants ha $\left.{ }^{-1}\right)$, were $3,603 \mathrm{~kg} \mathrm{ha}^{-1}$ and 4,265 $\mathrm{kg} \mathrm{ha}^{-1}$, respectively (Bremer et al. 2008), higher than those obtained in this study, despite the lower plant density.

In this study, the 'Emerald' and 'Jewel' cultivars had complementary harvest periods (Figure 3), allowing the extension of the fresh fruit

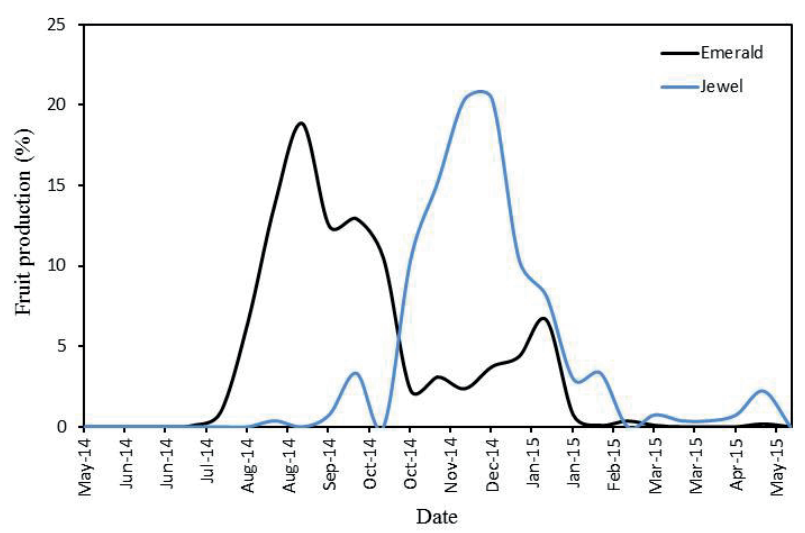

Figure 3. Monthly fruit production of 'Emerald' and 'Jewel' blueberry plants, demonstrating their complementary harvest seasons. 
supply for a period of up to six months by growing in both cultivars. Additionally, when planted together, the fruit harvest period extends over the off-season period in the domestic and foreign market, getting elevated prices paid for fresh blueberries in both markets (Fagundes 2007).

\section{CONCLUSIONS}

1. It is possible to cultivate 'Jewel' and 'Emerald' blueberry plants in a subtropical climate region without the occurrence of temperatures below $7.2{ }^{\circ} \mathrm{C}$;

2. The flowering stimulus for both cultivars occurs after the accumulation of a number of chill hours different and lower than that reported at the region of origin;

3. The 'Emerald' blueberry plants cultivated in a protected environment, in a subtropical climate region, presents a greater productive potential than the 'Jewel' plants;

4. 'Emerald' and 'Jewel' blueberry plants grown together in a subtropical climate (Cwa) yield fruit during the off-season of the internal and external markets, resulting in higher fruit prices.

\section{ACKNOWLEDGMENTS}

The authors thank the grower Luis Milner, from Chácara Catavento, for making possible the experiment; Coordenação de Aperfeiçoamento de Pessoal de Nível Superior (Capes), for the scholarship granted to R. B. Medina; and Conselho Nacional de Desenvolvimento Científico e Tecnológico (CNPq), for the grant awarded to S. R. Silva.

\section{REFERENCES}

BRAZELTON, C. World blueberry: acreage \& production. Folsom: USHBC, 2013.

BRAZELTON, C. World blueberry: acreage \& production. Folsom: USHBC, 2015.

BREMER, V. et al. San Joaquin valley blueberries evaluated for quality attributes. California Agriculture, v. 62 , n. 1, p. 91-96, 2008.

BYRNE, D. H. Trends and progress of low chill stone fruit breeding. In: GEORGE, A.; BOONPRAKOB, U. (Eds.). Production technologies for low-chill temperate fruits. Canberra: ACIAT, 2005. p. 5-12.
CANTUARIAS-AVILÉS, T. et al. Cultivo do mirtilo: atualizações e desempenho inicial de variedades de baixa exigência em frio no estado de São Paulo. Revista Brasileira de Fruticultura, v. 36 n. 1, p. 139-147, 2014.

FACHINELLO, J. C. Blueberry. Revista Brasileira de Fruticultura, v. 30, n. 2, p. 285-288, 2008.

FAGUNDES, P. R. S. Mercado e comercialização de amora, mirtilo e framboesa. Análises e Indicadores do Agronegócio, v. 2, n. 12, p. 3, 2007.

FOOD AND AGRICULTURE ORGANIZATION OF UNITED NATIONS (FAO). Faostat. 2018. Available at: $<$ http://faostat.fao.org/>. Access on: 22 Feb. 2018.

HUMMER, K. et al. Evergreen production of Southern Highbush blueberries in Hawaii. Journal of the American Pomological Society, v. 61, n. 4, p. 188-195, 2007.

LYRENE, P. M. ‘Emerald' Southern Highbush blueberry. HortScience, v. 43, n. 5, p. 1606-1607, 2008.

NORVELL, D. J.; MOORE, J. N. An evaluation of chilling models for estimating rest requirements of Highbush blueberries (Vaccinium corymbosurn L.). Journal of the American Society for Horticultural Science, v. 107, n. 1, p. 54-56, 1982.

OGDEN, A. B.; IERSEL, M. W. V. Southern Highbush blueberry production in high tunnels: temperatures, development, yield and fruit quality during the establishment years. HortScience, v. 44, n. 7, p. 18501856,2009

OLMSTEAD, J. W. et al. Floral bud chill requirement of low-chill Southern Highbush blueberry germplasm. Journal of the American Pomological Society, v. 69, n. 1, p. 4-10, 2015.

ZHENG, Y. et al. The optimal temperature for the growth of blueberry (Vaccinium corymbosum L.). Pakistan Journal of Botany, v. 49, n. 3, p. 965-979, 2017. 